\title{
CHANGES IN THE AGRICULTURAL PRODUCTIVITY OF SELECTED CROPS IN SINDHUDURG DISTRICT OF MAHARASHTRA STATE: A GEOGRAPHICAL ANALYSIS
}

\author{
KASHID DHANAJI LAHU* AND KASHID NITA DHANAJI AND SARANG S.B. ${ }^{1}$ \\ *Shri Shahaji Chh. Mahavidyalya, Dasara Chowk, Kolhapur, MS, India \\ ${ }^{1}$ Y. C. Warana College, Warananagar, Dist. Kolhapur, Maharashtra \\ ${ }^{*}$ Corresponding author. E-mail: Kashid Dhanaji Lahu
}

Received: December 14, 2010; Accepted: December 28, 2010

\begin{abstract}
Analytical study of agricultural productivity in Sindhudurg district is presented in this paper. The technique used has considered the average yield per hectare of selected crops and land occupancy of selected crops in the study region. For the study region considered for the present study for which available ranking coefficient are given in ascending order for each crop separately then crop yield and concentration indices ranking co-efficient of each crop are summed and divided by two. From the ranking coefficient calculated for 1981-86 and 2003-08 and categories are made according to the three efficiency grades viz. high grade, moderate grade and low grade for discussing the spatiotemporal variations in the study region. In a same way, overall ranking coefficient have been worked out by summing the values of all the selected crops in each tahsil and divided by 'n,' where ' $n$ ' refer to the number of crops considered. To avoid the annual fluctuations in the level of crop productivity there is considered average productivity level and statistics of five year i.e. 1981-86 and 2003-08.
\end{abstract}

\section{Introduction}

The area selected for the study i.e., Sindhudurg district in Maharashtra state in respect of agricultural productivity shows imbalance in agricultural productivity. Agriculture being the dominant primary activity of the study region it is essential to study important features of agriculture in the study region. Agriculture in any area is closely related to climatic conditions and topography. Productivity as defined in economic or agricultural geography means output per unit of input or per unit of area respectively and the importance of agricultural productivity is generally the result of a more efficient use of factors of production viz. environment, arable land, labour and capital (Jasbir Singh \& Dhillon S. S. 1997). Bhatia (1967) defined "Agricultural efficiency as the aggregate performance of various crops in regard to their output per acre but the contribution of each crop to the agricultural efficiency would be relative to its share of the crop land". The study of levels of agricultural productivity provides a base for rational planning. Its changing pattern is a reliable index to asses' agricultural development in the past. It will help in identifying weaker areas for agricultural planning in Sindhudurg district.

Aims and objective of the present study

To find out agricultural productivity and its variations in the study region is the main objective of the present study.

\section{Study Area}

Sindhudurg district is second smallest district in terms of size and population in Maharashtra state. Sindhudurg district lies between $15^{\circ} 37^{\prime}$ to $16040^{\prime}$ North latitude and 73019' to 740 13' East longitudes. The district is bounded by hilly region of Sahyadri range in the east and Arabian Sea towards the west. The outstanding features of the relief in the district are its highly uneven nature and very narrow riverine plains that fringe the coast line. There is no scope to bring more and more land under cultivation in the study region. Most of the rivers dry up in summer. The predominant soil in the district is laterate soil. The lateritic soil very in colour from red to brownish-red owning to the preponderance of hydrated iron oxide. This soil is suitable for crops like rice, cereals, and horticultural crops. About $92.41 \%$ of the total population is residing in the rural area and only $7.59 \%$ population is found in urban area. Thus the population base for primary activity like agriculture is available in the district.

\section{Database and Methodology}

For the present study the secondary data was collected for the nearly three decades i.e. the period from1981-82 to 2007-08. For the clear cut picture of the study of patterns of production and yield is made with the help of secondary data obtained from Socio-Economic Abstracts, District Census Handbooks, Season and Crop Reports, District 
Gazetteers, Agricultural Statistical Information from Agricultural Department of Maharashtra, Periodicals, some published and unpublished reports and records maintained by Zillah Parishads, Panchayat Samitis, Talathi offices. These involve the description and interpretation of the regional pattern revealed through choropleth method. To get a clear picture of productivity and spatial imbalances in the productivity the crop yield and concentration indices ranking co-efficient techniques are used which was introduced by Jasbir Singh (1976) in order to assess the regional differences in the level of food production and to delimit the weaker areas from the point of view of agricultural productivity the relative crop yield and concentration indices in ranking order and computed into average ranking coefficient. It may be called as the crop yield and concentration indices ranking coefficient. The procedure used is given below.

$$
Y i=\frac{\text { Yae }}{\text { Yar }} \times 100
$$

Where,

$\mathrm{Yi}=$ crop yield index .

Yae = average yield per hectare of crop ' $a$ ' in the component

enumeration unit.

Yar = average yield of the crop ' $a$ ' in the entire region.

$$
\mathrm{Ci}=\frac{\text { Pae }}{\text { Par }} \times 100
$$

Where,

$$
\begin{array}{ll}
\mathrm{Ci} & =\text { crop concentration index. } \\
\mathrm{Pae} & =\text { percentage strength of crop ' } \mathrm{a} \text { ' in the } \\
\text { total copped area in the } \\
\text { component enumeration unit. } \\
\mathrm{Par}=\text { percentage strength of crop ' } \mathrm{a} \text { ' in the } \\
\text { total cropped area in the } \\
\text { entire region. }
\end{array}
$$

$\begin{aligned} & \text { Crop yield and concentration } \\ & \text { Indices ranking co-efficient } \\ & \text { For crop 'a' }\end{aligned}=\frac{\begin{array}{l}\text { Crop yield index Crop Concentration index } \\ \text { ranking of crop 'a' + ranking of crop 'a' }\end{array}}{2}$

\section{Productivity Level of Selected Crops \\ Rice}

Table 1.1 and map $1.1 \mathrm{~B}$ indicate that moderate to low change in the level of rice productivity was observed in Malvan tahsil while high to low change in the level of rice productivity was observed in Devgad tahsil during 2003-08. No change in the level of rice productivity was observed in Kankavali, Kudal, Vaibhavwadi, Vengurla and Sawantwadi tahsils.

\section{Ragi}

Change from high level of ragi productivity to low level was observed in Kankavali tahsil, during the period of investigation. It is clear form the table 1.1 and map $1.2 \mathrm{~B}$ that no change in the level of ragi productivity took place in Sindhudurg district except Kankavali tahsil between 1981-86 and 2003-08.

\section{Vari}

It is clear from the map 1.3 that low to moderate level of vari productivity change took place in Vengurla Kudal and Sawantwadi tahsils and moderate to high level productivity change was observed in Malvan and Devgad tahsils. High to moderate level productivity change was noticed in Kankavali tahsil and no change in level of vari productivity was found in Vaibhavwadi tahsil during the period of 1981-86 and 203-08. Though the area under vari has decreased, per hectare yield has increased during the same period.

\section{Other Cereals}

In the case of other cereals low to moderate productivity level of change took place in Devgad, Vengurla, Kudal and Sawantwadi tahsils and moderate to high level productivity change was noticed in Malvan tahsil. High to low change was recorded in Vaibhavwadi tahsil (map 1.4 B). No change in the level of other cereals productivity was observed in Kankavali tahsil during the period of 1981-86 and 2003-08.

\section{Pulses}

As per table 1.1 low to moderate productivity level change was observed in Kudal tahsil and moderate to high productivity level change was seen in Malvan tahsil. High to moderate and low productivity level of pulses change was observed in Devgad and Knakavli tahsils respectively from the period of 1981-86 and 2003-08 (map1.5B). No change in the level of pulses productivity was recorded in Vaibhavwadi, Vengula and Sawantwadi tahsils.

\section{Spices and Condiments}

Low level to moderate level spices and condiments productivity change occurred in Kudal tahsil whereas moderate level to low level change was found in Devgad tahsil. High to moderate level change in the case of spices and condiments productivity was observed in Malvan tahsil and no change in the level of spices and condiment productivity was noticed in Vengurla, Vaibhavwadi and Kankavali tahsils during the period of 1981-86 and 2003-08 (map 1.6 B).

\section{Fruits and Vegetables}

In the case of moderate level to high level change took place in Sawantwadi tahsil and low level to moderate change was observed in Kankavali tahsil during the period between 1981-86 to 203-08. High 
level to moderate level change was experienced in Sawantwadi tahsil and moderate to low level change was seen in Kudal tahsil. No change in the level of fruits and vegetable productivity was noticed in Devgad, Vengurla and Malvan tahsils during the period 1981-86 and 2003-08 (map 1.7 B).

\section{Oilseeds}

No change in the level of oilseed productivity was found all over Sindhudurg district during the period $1981-86$ to 2003-08.

\section{Tahsil-wise Overall Productivity in Sindhudurg District}

The quantitative indication of changes in the case of overall productivity is shown in table 1.2. Categories of overall productivity given under fallow: 1. Area of High productivity
2. Area of Moderate productivity $110 \%$ to
$115 \%$

3. Area of Low productivity below $110 \%$ High overall productivity i.e. above $115 \%$ of selected crops was noticed in Vaibhavwadi and Vengurla tahsils while moderate overall productivity between 110 per cent and 115 per cent was found in Kankavali tahsil during 1981-86. Low overall productivity was recorded in Sawantwadi, Kudal, Devgad and Malvan tahsils during the same period (map 1.9).

Low level to high level overall productivity change has occurred in Sawantwadi tahsil and high to moderate change took place in Vaibhavwadi and Vengurla tahsils during the period of investigation. Moderate to low change was experienced in Kankavali tahsil whereas no change in overall productivity was seen in Kudal, Devgad and Malvan tahsils during the period of investigation.

\section{Concluding Remarks}

In the study region irrigation has become the key factor for promoting level of agricultural productivity. There are tahsils which records backward stage of agricultural productivity. The regional disparities in rainfall distribution, irrigation facilities, government policies and farmers attitude are correspondingly related to the spatial variations in agricultural productivity. The small river patches, endowed with fertile soils and irrigation facilities have attained significant productivity in agriculture.

The overall productivity of the selected crops varies from tahsil to tahsil in the study region. Human traditions, irrigation possibilities and agricultural practices are together ten to influence the overall productivity in the study region. Underdeveloped economy of study region, limitations imposed by the nature of soils, topography and the scarcity of water supply are the factors responsible for the variation in overall productivity in the study region. It means that the physical and non physical determinants of agricultural factors made an impact on overall productivity of study region.

\section{References}

[1] Jasbir Singh and Dhillon S. S. (1997):"Agricultural Geography" Mc Graw Mill Publishing co. Ltd. New Delhi p. 226.

[2] Bhatia S.S. (1967) Economic Geography, Vol. 43, pp. 224-260.

[3] Dayal Edison (1984) Annals of the association of American Geographers vol.74, No. 1 p. 98-120.

[4] Kendall M. G. (1939) Journal of the Royal Statistical Society, pp. 24-28.

[5] Jadhav M. G. (1997) Transactions Institute of Indian Geographers, Vol.19, No.1, Jan 1997, p.39.

[6] Shafi M. (1960) Economic Geography, 36 (4), pp. 296-305.

[7] Sapre and Deshpande V. D. (1964) Indian Journal of Agricultural Economics, 19.

[8] Shaffi M. (1972) The Geographers, pp. 413.

[9] Shaffi M. (1974) The Geographer, pp. 6-8.

[10] Hussain M. (1976) Geographical Review of India, 230-236.

[11] Singh V. R. (1979) Transactions, 30-46.

[12] Singh Jasbir (1982) 'Determinant of Agricultural Productivity in Hariyana": A Sample Study of Operational Holdings for Landuse planning, Kurukshetra, Vishal Publications p. 509. 
Changes in the agricultural productivity of selected crops in Sindhudurg District of Maharashtra State

Table No. 1.1- Tahsilwise productivity of selected crops in Sindhudurg District (1981-86 and 2003-08)

\begin{tabular}{|c|c|c|c|c|c|c|c|c|c|c|}
\hline \multirow[b]{2}{*}{$\begin{array}{l}\text { Sr } \\
\text { No }\end{array}$} & \multirow[b]{2}{*}{ Tahsil } & \multirow[b]{2}{*}{ Year } & \multicolumn{8}{|c|}{$\begin{array}{l}\text { Crop yield and concentration indices ranking coefficient of selected } \\
\text { crops }\end{array}$} \\
\hline & & & $\frac{\mathscr{J}}{\widetilde{L}}$ & চ্ত্ণে & $\frac{5}{\frac{1}{5}}$ & 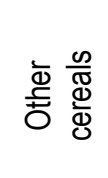 & 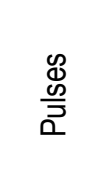 & 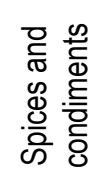 & 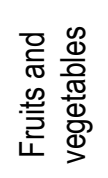 & 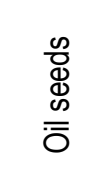 \\
\hline \multirow[t]{2}{*}{1} & \multirow[t]{2}{*}{ Devgad } & $1981-86$ & 112.4 & 142.54 & 98.09 & 82.67 & 125.42 & 93.25 & 132.05 & 73.65 \\
\hline & & 2003-08 & 97.61 & 102.83 & 161.07 & 105.78 & 119.64 & 80.57 & 129.85 & 78.85 \\
\hline \multirow[t]{2}{*}{2} & \multirow[t]{2}{*}{ Vaibhav wadi } & $1981-86$ & 96.62 & 134.88 & 265.98 & 146.46 & 72.0 & 53.49 & -- & 69.9 \\
\hline & & 2003-08 & 99.4 & 161.15 & 226.86 & 97.26 & 72.39 & 88.09 & 71.67 & 70.23 \\
\hline \multirow[t]{2}{*}{3} & \multirow[t]{2}{*}{ Kankavali } & $1981-86$ & 109.4 & 110.23 & 170.36 & 167.97 & 149.85 & 58.65 & 66.59 & 72.72 \\
\hline & & $2003-08$ & 106.3 & 61.46 & 97.12 & 147.68 & 96.4 & 53.57 & 100.66 & 79.3 \\
\hline \multirow[t]{2}{*}{4} & \multirow[t]{2}{*}{ Malvan } & $1981-86$ & 101.2 & 95.79 & 88.97 & 127.34 & 117.93 & 112.46 & 92.7 & 131.03 \\
\hline & & 2003-08 & 978.55 & 77.75 & 119.07 & 135.62 & 130.65 & 94.84 & 99.78 & 121.78 \\
\hline \multirow[t]{2}{*}{5} & \multirow[t]{2}{*}{ Vengurla } & $1981-86$ & 90.98 & 60.34 & 66.73 & 47.6 & 85.13 & 216.66 & 172.57 & 208.21 \\
\hline & & $2003-08$ & 84.52 & 47.7 & 89.93 & 104.14 & 73.09 & 194.84 & 129.18 & 156.91 \\
\hline \multirow[t]{2}{*}{6} & \multirow[t]{2}{*}{ Kudal } & $1981-86$ & 114.5 & 66.21 & 61.04 & 76.65 & 89.53 & 81.96 & 92.1 & 83.83 \\
\hline & & $2003-08$ & 108.6 & 70.14 & 112.42 & 112.53 & 102.92 & 96.82 & 81.7 & 95.66 \\
\hline \multirow[t]{2}{*}{7} & \multirow[t]{2}{*}{ Sawantwadi } & $1981-86$ & 95.85 & 132.02 & 65.75 & 85.11 & 75.29 & 136.82 & 143.03 & 113.81 \\
\hline & & 2003-08 & 95.55 & 175.56 & 84.53 & 120.94 & 99.18 & 159.13 & 98.41 & 110.4 \\
\hline
\end{tabular}

Source: Socio-Economic Abstracts of Sindhudurg District from (1981-86) and (2003-08).

Table 1.2- Changes in the Overall Productivity of Selected Crops in Sindhudurg District

\begin{tabular}{|l|l|c|c|c|}
\hline Sr.no. & Tahsil & $\mathbf{1 9 8 1 - 8 6}$ & $\mathbf{2 0 0 3 - 0 8}$ & Changes in \% \\
\hline 1 & Devgad & 107.50 & 109.51 & 2.01 \\
\hline 2 & Vaibhavwadi & 119.9 & 110.88 & -9.02 \\
\hline 3 & Kankavali & 113.22 & 92.77 & -20.45 \\
\hline 4 & Malvan & 108.42 & 109.71 & 1.29 \\
\hline 5 & Vengurla & 118.52 & 110.03 & -8.49 \\
\hline 6 & Kudal & 83.22 & 97.59 & 14.37 \\
\hline 7 & Sawantwadi & 105.96 & 117.96 & 12.00 \\
\hline
\end{tabular}

Source : Socio-Economic Abstracts of Sindhudurg District from (1981-86) and (2003-08). 


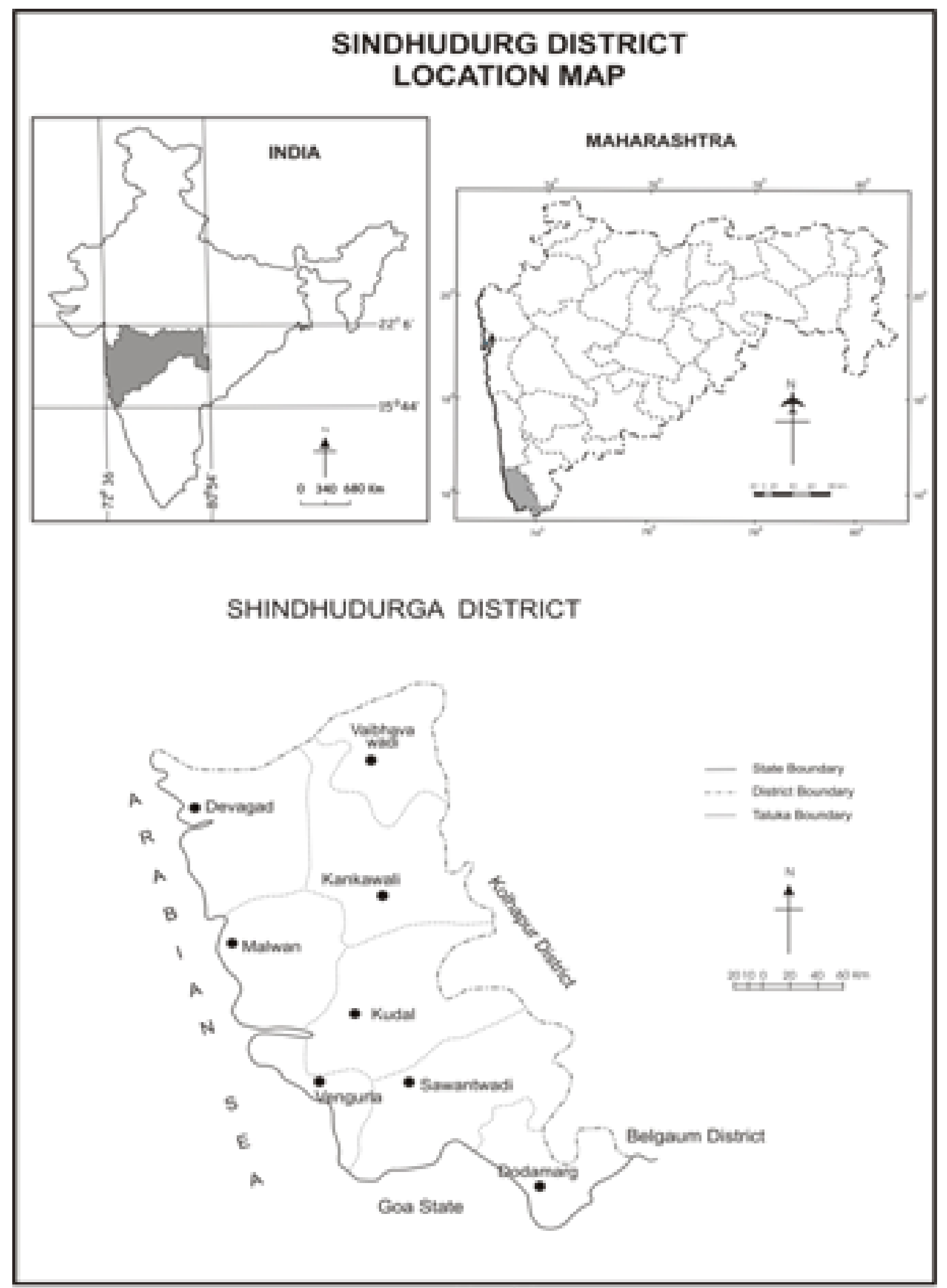

Mop 21 
Changes in the agricultural productivity of selected crops in Sindhudurg District of Maharashtra State

\section{Changes in the Productivity of Selected Crops in Sindhudurg District}

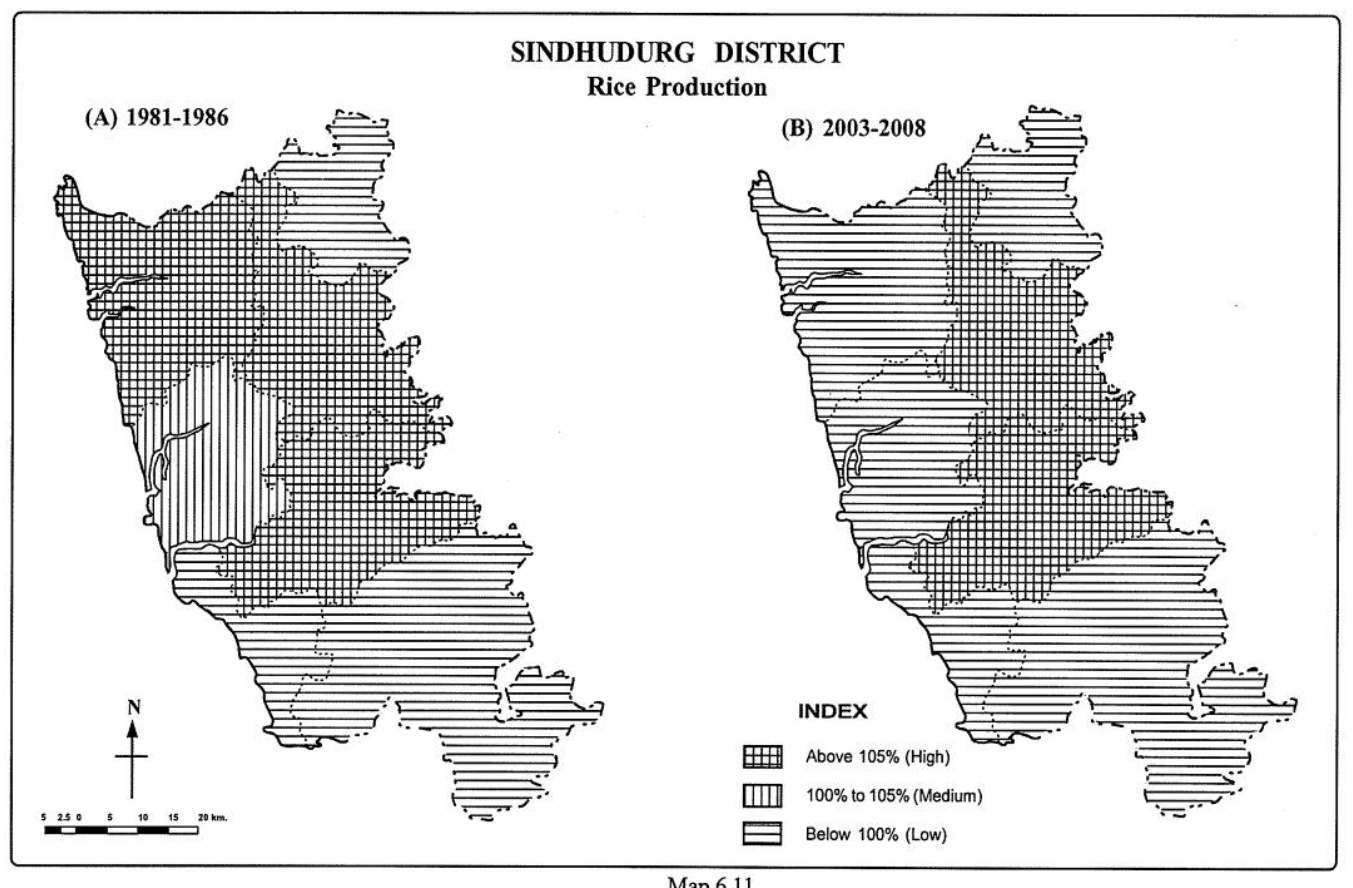

Map 6.11

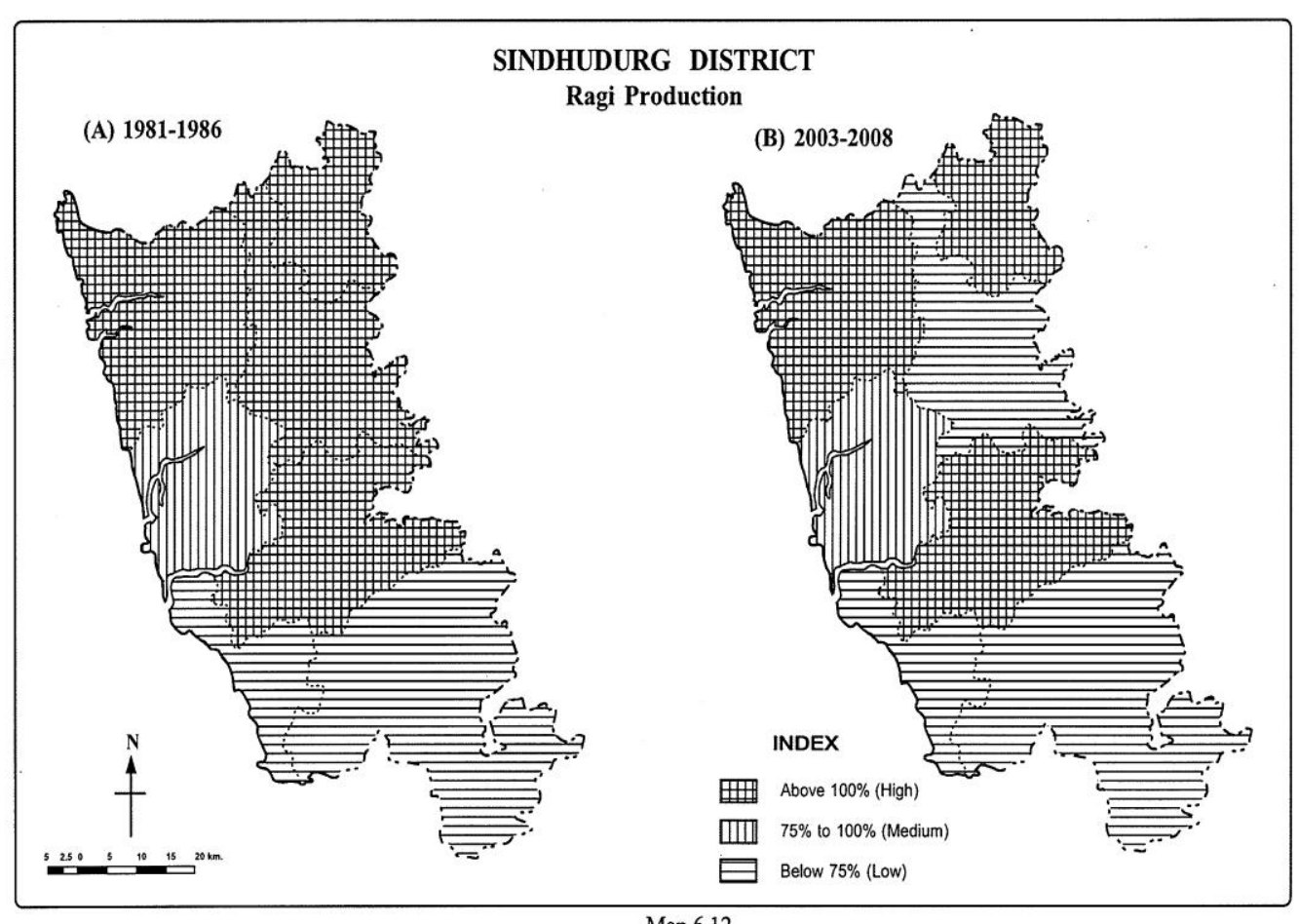

Map 6.12 

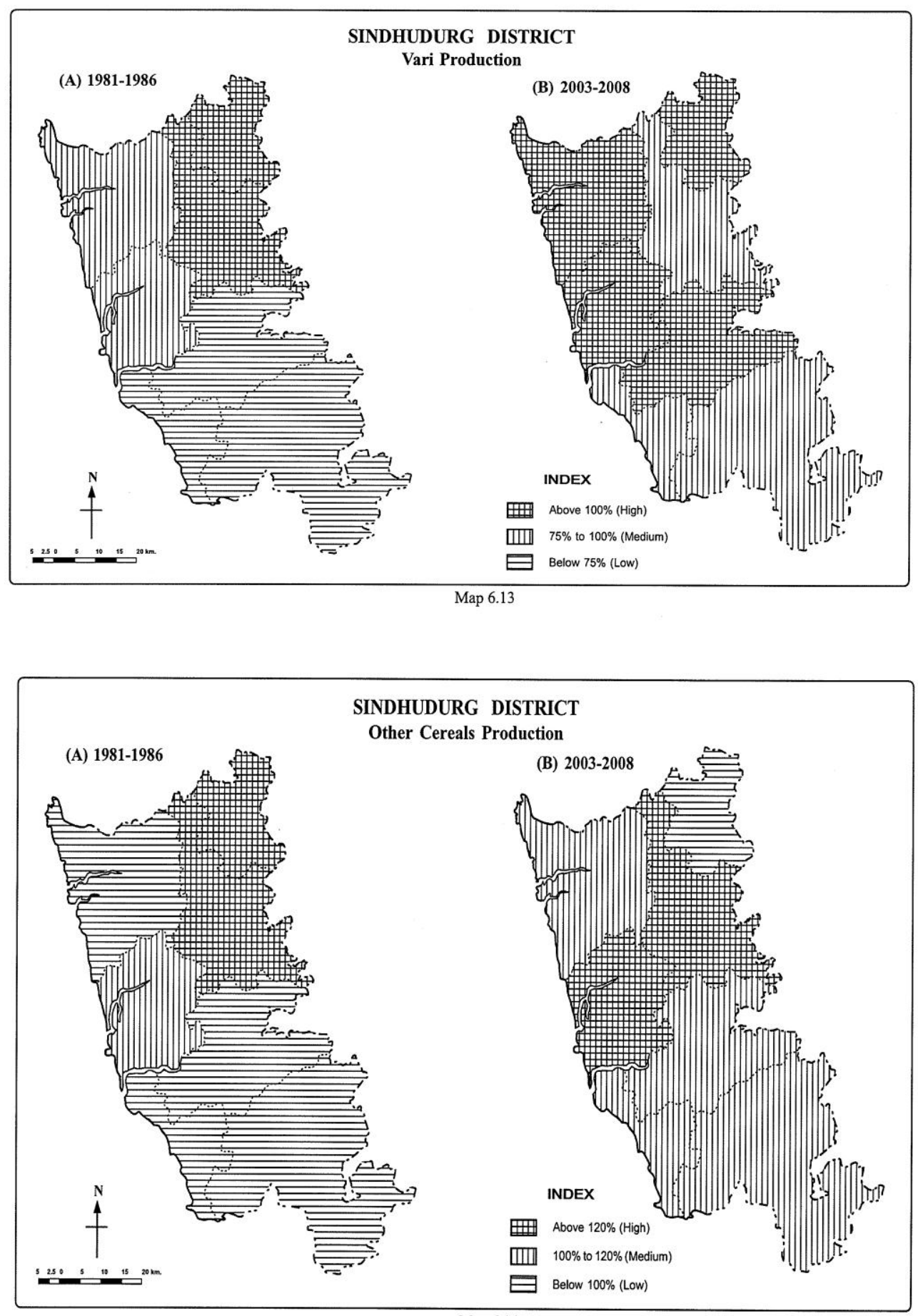

Map 6.14 


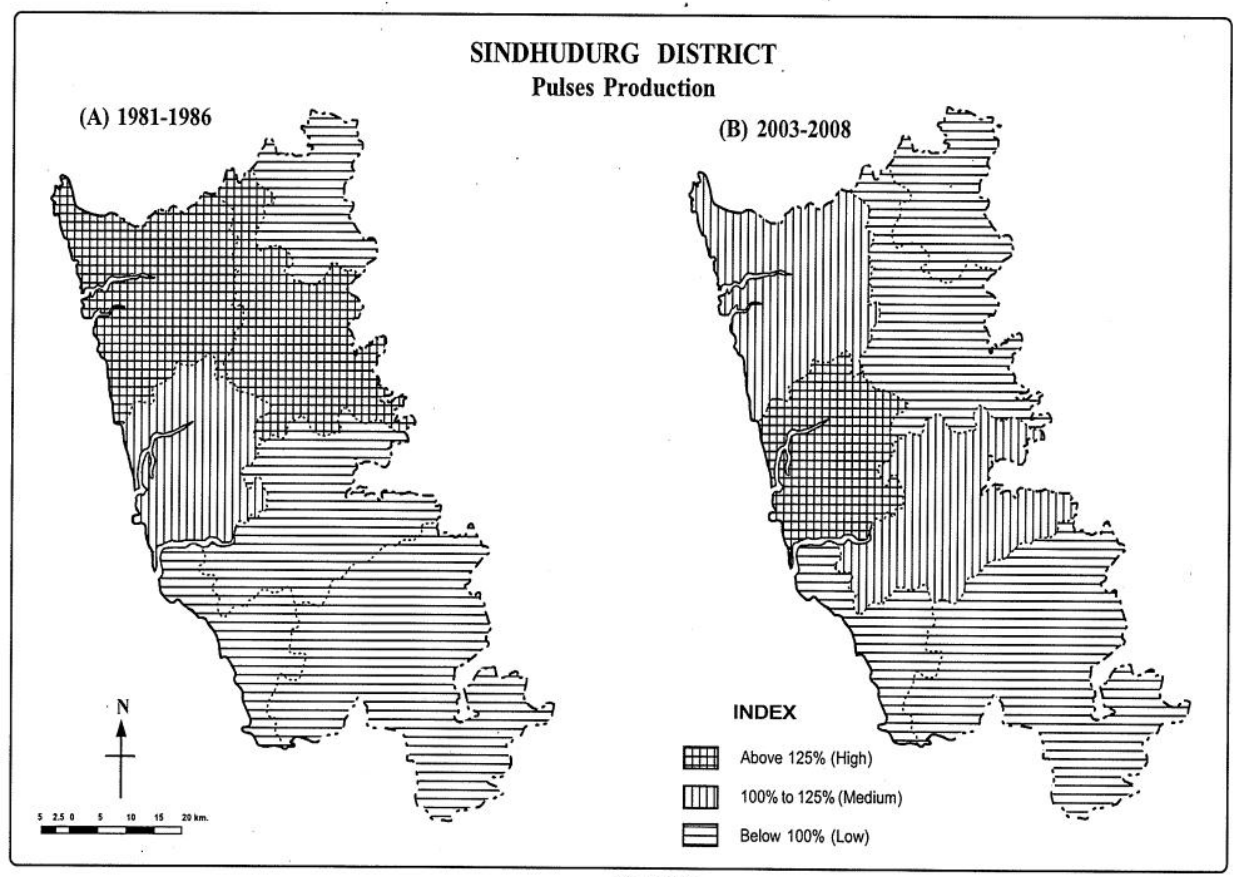

Map 6.15

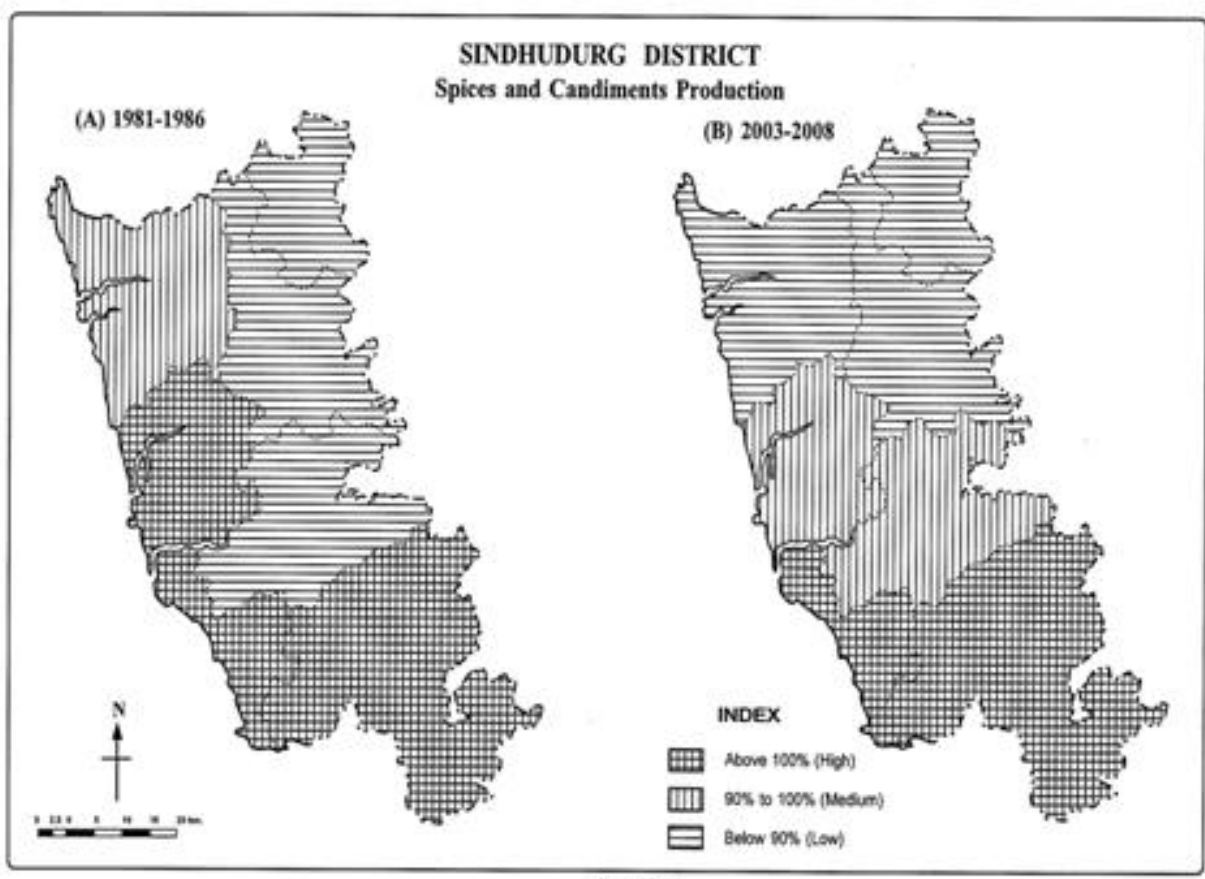

Map 6.16 

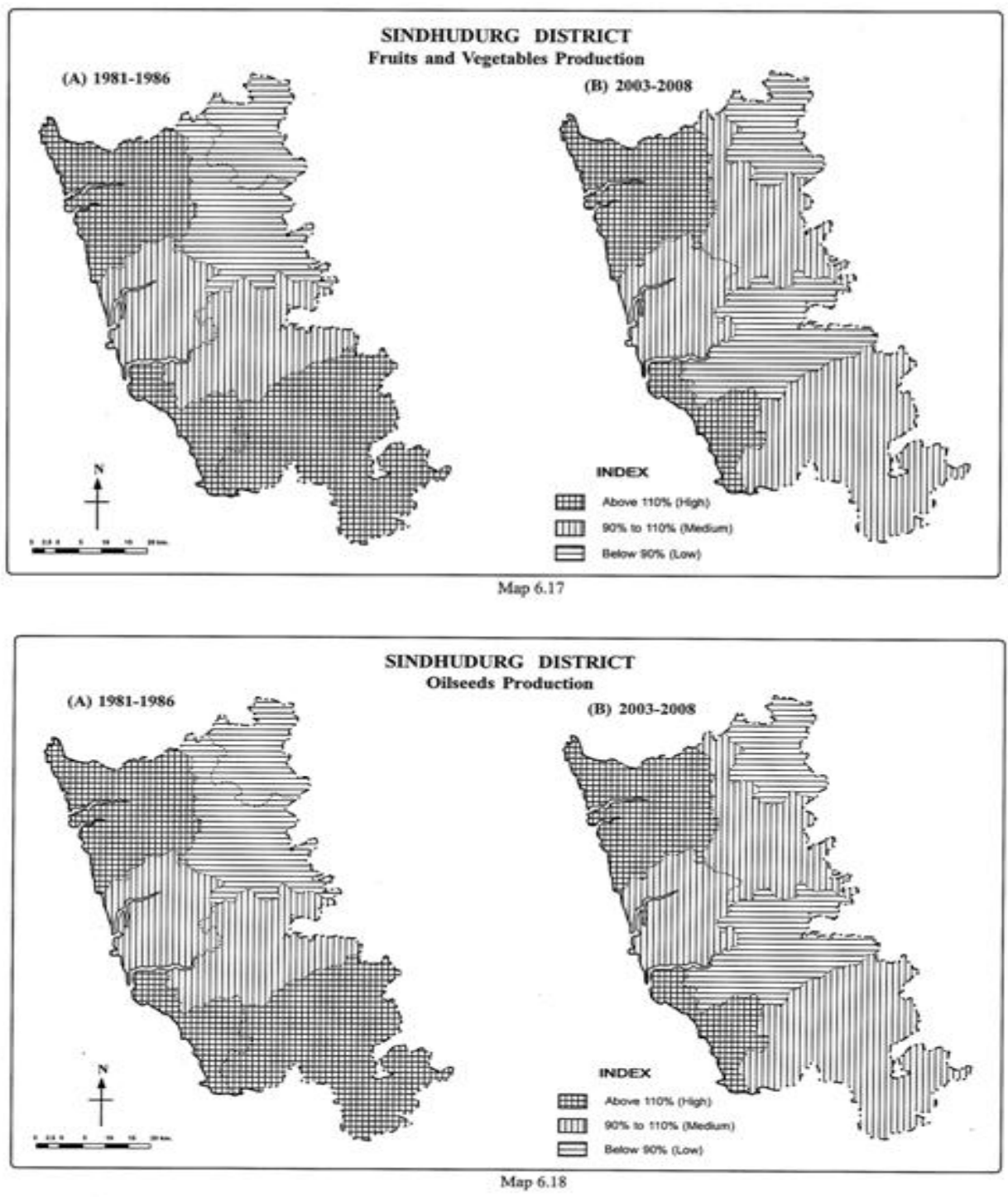

Changes in the Overall Productivity of Selected Crops in Sindhudurg District

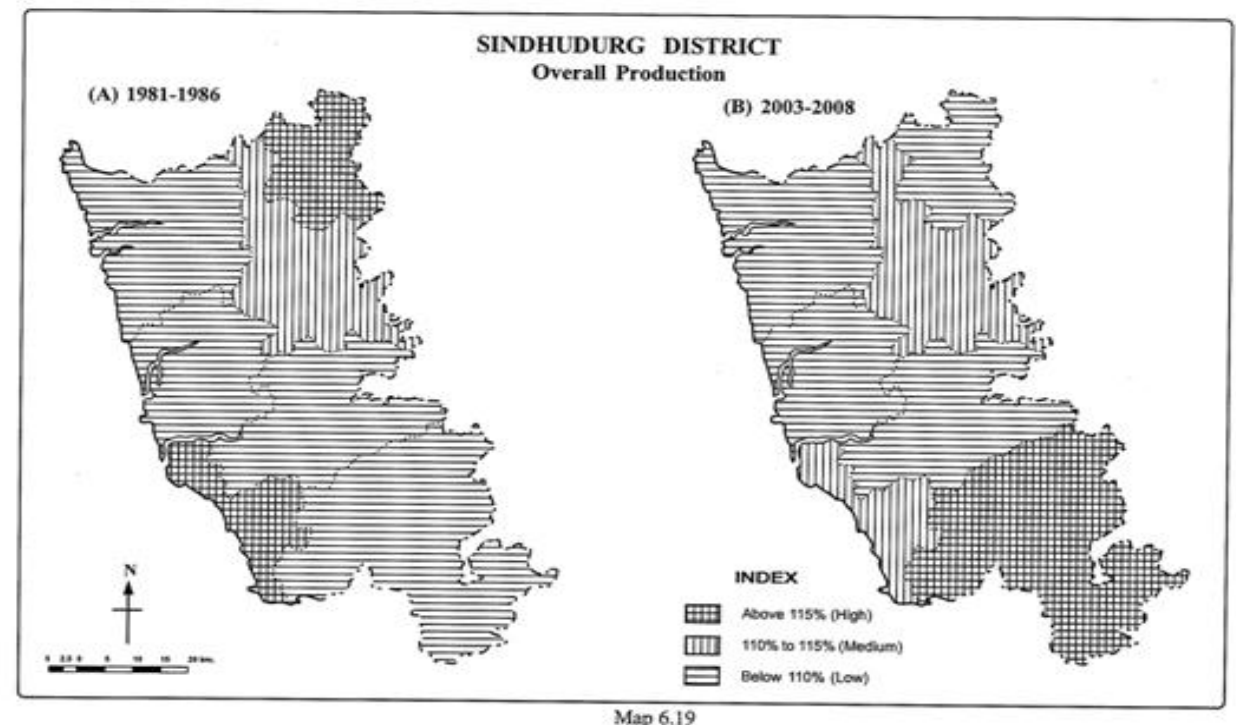

